\title{
National Wisdoms and The ASEAN Human Rights Legal Regime
}

\author{
Heribertus Jaka Triyana*
}

Lecturer at Faculty of Law Universitas Gadjah Mada, Yogyakarta, Indonesia

\begin{abstract}
Recently, the discourse on the relation between local wisdom and human rights shows its relevance. This article describes and critically examines the human rights norms and procedures with regards to common local wisdoms to remedy and redress human rights problems in South East Asian countries. It takes an example of redressing problem in rights to development and also focuses on the application of the ASEAN agreement on Disaster Management Response to contextualize role and influence of local wisdoms to manage and to mitigate disaster response within the ASEAN human rights protection. This writing also highlights that human rights based approach is needed in the implementation of the ASEAN human rights norms and mechanisms in accordance to local wisdoms of respective countries where disaster occurs.
\end{abstract}

Keywords: Wisdom, ASEAN, Human Rights.

\section{INTRODUCTION}

As the newest sub regional legal regime, the Association of the South East Asian Nations (ASEAN) has developed its own human rights norms and mechanisms, ${ }^{1}$ that truly inspired by local wisdoms among its member States. It has then created a distinct legal human rights regime. ${ }^{2}$ The establishment of the ASEAN Intergovernmental Commission on Human Rights (AICHR) in 2009 and the creation of the ASEAN Human Rights Declaration (AHRD) in 2012 marked tremendous development of human safety and security for Southeast Asian countries. ${ }^{3}$ Then, human rights-based organization is legally labelled and dedicated to ASEAN. As a result, it shall achieve its main goals within the human rights-based approach as the manifestation of a comprehensive human security for reaching the ASEAN idea of one community. ${ }^{4}$

It is important to note that the agreement among the ASEAN member States indicates a common acceptance over the binding legal righteous and legal entitlement

* Correspondence: jaka.triyana@mail.ugm.ac.id

1 Direktorat Jenderal Kerjasama ASEAN Deplu, ASEAN Selayang Pandang (2007), 41 and Phnom Penh Statement on the Adoption of the ASEAN Human Rights Declaration (AHRD) (18 November 2012).

2 Yuyun Wahyuningrum. "Regional Limitation and Universality of Human Rights in ASEAN" (Paper Presentation at the Padjadjaran International Conference on International Law, Faculty of Law Padjajaran University - Bandung, 2013).

3 ASEAN. 2010. ASEAN Masterplan 2020 (Bangkok: ASEAN, 2008), 26.

4 Heribertus Jaka Triyana. "Politics and Law of Human Rights in Southeast Asia: A Critical Legal Analysis" (Presented at the Short Course on Human Rights and Democracy in Southeast Asia for the ASEAN Diplomats, 24-25 August 2009, Pusat Studi Sosial Asia Tenggara (PSSAT UGM)-Deplu RI, Yogyakarta, 2009), 3-7. 
of the terms of human rights within ASEAN contexts and perspectives. ${ }^{5}$ Legal expectation then could be built throughout South East Asian countries in terms of human rights advocacy and adjudication for better human rights protection or enjoyment. ${ }^{6}$ Redress and remedies must be guaranteed by all member States and by ASEAN it self. ${ }^{7}$ Indeed, they direct member States to comply with the ASEAN human rights standards for better enjoyment and for more progressive realization. ${ }^{8}$

The terms of human rights in ASEAN instruments have distinct features compared with internationally recognised documents, such as the Universal Declaration of Human Rights; and with the existing regional human rights conventions, such as the European Human Rights Conventions and Fundamental Freedoms, the Inter American Convention on Human Rights, and the African Charter on Human Rights and Peoples' Rights. ${ }^{9}$ Undeniably, common concerns from all ASEAN member states have shaped its contents and procedures. ${ }^{10}$

National identities and local wisdoms being apart from unfinished debates on the Asian values, and national interests are posted as three pillars of the human rights concept in the ASEAN scheme. ${ }^{11}$ They are representing freedom, integrity and equality of common terms of human rights. As a consequence, this creation emphasises collective rights such as right to development, right to peace, and economic and social rights.

Further, common regional problems and challenges to migrant workers, human trafficking of children and women, and terrorisms have been construed as common human rights violations that need common efforts to combat, remedy, and give redress to these violations, in terms of future ASEAN cooperation. ${ }^{12}$ Integration of common policy, program and action to these matters has reached deeply regional understanding and patterns of mutual cooperation. As a result, individual as well as collective legal expectation could be far more strengthened for effective and more practical advocacy and adjudication. Indeed, they are intended to be complemented

5 Heribertus Jaka Triyana, "Tinjauan Yuridis Tentang Badan HAM ASEAN Dalam Sistem Hukum Nasional Indonesia", Jurnal Mimbar Hukum FH UGM 23, No. 3 (2011): 612-623.

6 Charles R Beitz, The Idea of Human Rights, (London: Oxford University Press, 2009), 10 \& 73.

7 Yigen, et all, National Human Rights Institutions: Articles and Working Papers, The Danish Center For Human Rights (Denmark: Wilden Plada, 2004), 44; Mortem Kjaerum,National Human Rights Institution Implementing Human Rights (Leiden: Martinus Nijhoff Publisher, 2003), 2-4; and Pacific Forum Secretariat, National Human Rights Institutions Pathways of the Pacific States (Pacific Islands Forum Secretariat, 2010), 2-10.

8 Human Rights Resource Center, Rule of Law Untuk Hak Asasi Manusia di Kawasan ASEAN, Studi Data Awal (Jakarta: UI Press, 2001), 10 and Charles R Beitz, The Idea of Human Rights.

9 Todd Landman, Studying Human Rights (New York: Routledge, 2006), 4.

10 Camoying Luningning G, "Establishing an ASEAN Human Rights Mechanism: Development and Prospects", Insights, Issue No. 1 March 2005 (2005), 1-3.

11 ASEAN, ASEAN Masterplan 2020, No. 3, 26.

12 Regarding the human trafficking of children and women, See ASEAN, ASEAN Handbook on International Cooperation in Trafficking in Persons (Jakarta: ASEAN Public Affairs Services, 2010), 49. 
by international human rights standards while they also require primacy for effective and practical national implementation among its ten member States. ${ }^{13}$

ASEAN currently faces problems, challenges, and opportunities viewed from both political and legal point of views. ${ }^{14}$ How can national wisdoms, interests, resilience and economic hegemony be used to make consensus and consultation for human rights campaign within the ASEAN human rights system?

Regional as well as sub regional human rights systems are established to complement the national system since national legal system shall comply with international legal norms and standard to protect human rights and fundamental freedoms; this theory justifies regionalism in the studies of international relations relevant to regional human rights needs and particularities. It also helps reduce critics of utilitarianism that human rights are nonsense concept, communitarians that human rights are as a matter of fantasy, and Marxism that human rights are bourgeois. In addition, it accepts sovereignty as responsibility for better human security in modern study in international law and international relation. In simple terms, this theory amplifies that the field of human rights has reshaped international law's character of coexistence to cooperation and integration. It is believed that ASEAN has reached into deeper element of cooperation, e.g. deep integration as a single community bound by common wisdoms of respecting integrity, freedom and equality. In this context, ASEAN human rights system reforms state sovereignty in a modest way into 'sovereignty as responsibility'.

This article aims to describe and critically examine the ASEAN human rights norms and mechanism as the agreement of common local wisdoms to remedy and to redress common human rights problems in South East Asian countries which mounting binding legal righteous and entitlement. ${ }^{15}$ It will take an example on redressing problems on rights to development. In particular, it will focus on the application of the ASEAN Agreement on Disaster Management Response (AADMER) to contextualize role and influence of local wisdoms to manage and to mitigate disaster response within the ASEAN human rights protection. In addition, coordination and cooperation will be initiated to reveal community participation.

This article is construed as follows. First, an introductory section describes the development of human rights in ASEAN, the aim of the writing, and the structure of the

13 Jo Stingen, The Relationship Between the International Criminal Court and National Jurisdictions, The Principle of Complementarity (Leiden: Martinus Nijhoff Publishers, 2008), 6-8; JT Holmes, "The Principle of Complementarity", in Lee, R.S, (Ed), The International Criminal Court: The Making of the Rome Statute, Issues Negotiations Results (The Hague, Boston: Kluwer Law International, 1999), 41 and J.T Holmes, "Complementarity: National Court vs. the ICC", in Antonio Cassese et all. (eds), The Rome Statute of the International Criminal Court (London: Vol. I, Oxford University Press, 2002), 667-668.

${ }^{14}$ Camoying Luningning G., "Establishing an ASEAN Human Rights Mechanism: Development and Prospects, 4.

${ }^{15}$ Hiro, Katsumata, ASEAN's Cooperative Security Enterprise, Norms and Interests in the ASEAN Regional Forum (Palgrave McMilan, 2009), 8-11. 
article. Second, it will elaborate local wisdoms and national interests to overcome common human rights problems within the ASEAN regime as well as to advocate and to adjudicate human rights violations. A focus on the right to development, in particular attention to the application of the AADMER, is emphasized on materialising this elaboration. Lastly, a concluding remarks will propose shortcomings to remedy efficacy of the existing norms and mechanisms.

\section{LOCAL WISDOMS FOR ASEAN HUMAN RIGHTS TO DEVELOPMENT ADVOCACY}

The adoption of local wisdoms for the application of ASEAN human rights norms and mechanisms can be seen in the ASEAN Agreement on Disaster Management Response (AADMER) which requires simplification of coordination and cooperation in terms of advocating human safety and security in South East Asian countries. Disaster forms legal concept in human rights since it creates certain legal rights and obligations to right holders and duty bearers. It also determines their specific roles and function when certain situation disrupts their normal livelihood. Determination of subjects, objects, facilitators, resource providers and collaborators is imminent to clarify their tasks according to right to development legal concepts in the AHRD and in the AADMER.

As a legal concept, the human rights-based approach is essential for the implementation of the ASEAN human rights norms and mechanisms in accordance to local wisdoms of respective countries where disaster occurs. This approach is a conceptual framework for the process of human development that is normatively based on international human rights standards and operationally directed to promote and protect human rights. It redefines ${ }^{16}$ context and perspective for its legal relevance in order to enhance its accountability and its sustainability aspects in sustainable development process. This understanding will be valuable to draw clear rights and obligations among stakeholders. ASEAN takes similar adaptation to this working definition in its regional cooperation and coordination in AADMER.

Take for example, the Indonesian legal system. The Law No. 39 of 1999 concerning Human Rights adopts this conceptual framework as it determines that the human rights-based approach requires State "to implement the effectiveness principle which obliges provisions of human rights treaties to be interpreted and applied so as to make their safeguards practical and effective in Indonesia". ${ }^{17}$ Within this legal point of view, this approach introduces and imposes legal obligations in which

\footnotetext{
${ }^{16}$ United Nations High Commissioner for Human Rights, Frequently Asked Questions on A Human Rights Based Approach to Development Cooperation (New York: UN Publisher, 2006), 15, http://www.ohchr.org/Documents / Publications/FAQen.pdf

17 The Law No. 39 of 1999 concerning Human Rights, Art.71.
} 
communities shall exercise their rights. Additionaly, this approach places them as a subject of development rather than as an object guaranteed by government.

Commonly, although the right to development is still debatable in terms of its legal rights and its legal duties, ${ }^{18}$ it is widely accepted and repeatedly voiced by developing countries and least developing countries when they negotiate international law instruments thay may potentially affect their right of self determination and their own development process. From the legal point of view, the right to development is accepted as part of human rights from which the human rights based-approach is developed to empower local communities in the sustainable development process. In Indonesia, for example, the corpus of the right to development, such as true participation and equality principle, plays its significance. It emerges as two basic indicators of the human rights-based approach relevant for the implementation of the AADMER which is guided by the application of the community based natural resources management system principle.

Viewed from the Indonesian contexts and perspectives of the AADMER's implementation, it depends on availibility and accessibility of natural resources. The National Disaster Management Process (NDMP) was introduced by applying the human rights-based approach to certain targeted groups. ${ }^{19}$ It reveals indicators of the obligation of conduct and of the obligation of result for progressive realization of the economic, social and cultural rights values. The fulfilment of the indicators of availability, accessibility, acceptability and adaptability ${ }^{20}$ is used to verify these two obligations for the implementation of the NDMP as regulated in the law of disaster.

Consequently, the Indonesia's ratification and other ASEAN member States'ratification and accession toward the International Covenant on Civil and Political Rights (ICESCR) make them bind to conduct those obligations guided by good faith. They indeed require governments to take "a commitment to act in accordance with the object and purpose of the ICESCR achieving a visible and meaningful result for its community and creating conducive context where the economic, social and cultural rights can be respected and experienced by its community". The Committee on Economic, Social and Cultural Rights (CESCR) further emphasises minimum indicators measuring States' compliance to achieve progressively the full realization of these rights.

According to Rehman, the examinations of those four indicators have tended to be assessed in a less attention manner by States Parties to the ICESCR, includ-

\footnotetext{
${ }^{18}$ David Hunter, James Salzman, and Durwood Zaelke, International Environmental Law and Policy (New York: Foundation Press, 2002), 383.

${ }^{19}$ Heribertus Jaka Triyana, “The Implementation of Natural Disaster Management Program in Indonesia Between 2007 and 2013", Mimbar Hukum 25, No. 1(2011), 105-107.

${ }^{20}$ These four indicators are developed by the Committee of the Economic, Social and Cultural Rights (CESCR) in its general comments directed to specific rights contained therein such as the right to development, the right to work, the right to housing, the right to health and the right to education.
} 
ing Indonesia. ${ }^{21}$ The Indonesian government has tended to be reluctant to apply the aforementioned standards, as the examinations are fully contained with political issues for the fulfilment of the Indonesia's obligations toward the ICESCR which somehow determines the AADMER implementation. Consequently, they will reach into political arena placing the government as the centre of attention rather than attention to their substantial relevance to the NDMP under the Law No. 24 of 2007 concerning Disaster Management.

According to the CESCR's point of view, the human rights-based approach conceptual framework can be examined by these four indicators related to two intrinsic values differentiated between the external and internal objective conditions. They are valued by element of the true participation from community and the equality of enjoyment of the rights in ASEAN. The two values will be further explained as follows. First, they place the roles of the government as an active actor for assessment of the accessibility and availability indicators. Second, the requirement of active involvement of community for assessment of the indicators of adaptability and acceptability is paramount to the first assessment for the implementation of the principle of the community based natural resources management system in all the NDMP. All of them shall be prudently taken into account in all six phases of the NDMP process, i.e. undertaking groundwork, selecting the community, building rapport and understanding participatory natural disaster risk management, increasing communitybased natural disaster risk management planning, managing community-managed implementation of risk reduction measures, and involving participatory monitoring and evaluation process. ${ }^{22}$

To sum up, the human rights-based approach for the implementation of the AADMER not only places it as "the logical framework of analysis" but also places it as "the objectively verified indicators" for conducting community resilience toward human hazards. This reveals the equal distributions of rights and duties among stakeholders based upon the true participation and the equality principle in the ASEAN human rights to development advocacy. Respect for this principle shows that local wisdom from society has enhanced community reliabilty on potential human hazards on the development process.

For example, Indonesia approved the AADMER on 5 May, 2008 by Presidential Regulation Number 32 of 2008 regarding the Acceptance of the AADMER in Indonesia. ${ }^{23}$ It seems that norm on disaster response is considered less important matter compared with the aforementioned aspects. In that regulation, there is no explicit

21 J. Rehman, International Human Rights Law, A Practical Approach (Longman: Pearson Education Limited, 2003), 23.

${ }^{22}$ Asian Disaster Preparedness Center, Critical Guidelines Community-Based Disaster Risk Management (Bangkok, 2006), 28-45 http://www.preventionweb.net/files/9440_ADPCCriticalGuidelines.pdf

23 Official State Gazette No. 73 of 2008. It only has three articles namely statement of approval, interpretation of the agreement and entry into force of the Agreement. 
AADMER's norm revealing difficulty to understand its scope, area and objective. Interestingly, the AADMER's norm was actually taken into account when the Disaster Management Law was enacted on 26 April 2007 without any acknowledgment to this regulation. One hand, the Law partially adopts the AADMER's norm such as principles of disaster response ${ }^{24}$, coordination and regional cooperation. ${ }^{25}$ On the other hand, it affirms the AADMER as the proactive regional framework for cooperation, ${ }^{26}$ coordination, ${ }^{27}$ technical assistance ${ }^{28}$ and resource mobilization in all aspects of disaster response. ${ }^{29}$ Consequently, this adoption has inspired the issuance of Government Regulation Number 22 of 2008 concerning Financial Arrangement of the Disaster Management and Government Regulation Number 23 of 2008 regarding the Role and Function of International Organizations on Disaster Management. ${ }^{30}$

It is inferred that local wisdoms inspires the incorporation of human rights to development in the ASEAN human rights norms and mechanisms. Vice versa, they also need to be institutionalised at national level by incorporating them into national laws, policies, programs, actions and fundings. The existence of local wisdoms is hand in hand with national and regional development processes in the ASEAN cooperation. They work in complementary way reaching simple determination of common objectives of ASEAN, i.e. living together in peace and harmony, friendly relations among nations and maintaining peace and security in the region. ${ }^{31}$ It is a continuum process of development that will be evolved in terms of its substance as well as its procedural matters. In this regards, local wisdoms may be used as a

${ }^{24}$ Article 3 regulates that disaster response shall be guided by principles of priority, prompt, effective coordination and cooperation, partnership, sustainability, empowerment and transparency which are also principles recognised in the AADMER.

25 Article 10 establishes the National Board of Disaster response whose functions are to coordinate and to maximize all efforts for disaster response; and Article 28 regulates regional and international cooperation of the disaster response in Indonesia.

${ }^{26}$ Chapter VI of the Law prescribes the role and functions for effective cooperation between international humanitarian institutions and the government in disaster management in Article 28 and 30 . Effective coordination in mitigation, emergency and reconstruction and rehabilitation are specifically stipulated in Article 33. In Article 30, consent and appeal-based cooperation have been set to foster national and international cooperation of disaster management.

${ }^{27}$ Chapter IV of the Law regulates effective coordination between national, regional and local disaster management institutions whose functions are extensively set in Articles 10 to 27. Effective coordination in mitigation, emergency and reconstruction and rehabilitation are specifically determined in Articles 33.

${ }^{28}$ Chapter IX of the Law prescribes technical assistance in terms of supervision in the making of all disaster-friendly policy management in all sustainable development processes. Article 71 determines that technical assistance shall be provided in: identification of threat, potential policy making disaster, exploitation activities, usage of goods and services, planning in the use of land, management of natural resources, reclamation and budget-based allocation for disaster management.

${ }^{29}$ Chapter III of the Law regulates on resource mobilization by specifying the responsibilities and authorities among disaster management stakeholders and beneficiaries in a very rigid attribution. For example, Articles 5 and 8 states that Government and local government have primary responsibilities to assess and to guarantee the fulfillment of basic needs of the refugees and internally displaced persons during emergency phase.

${ }^{30}$ Government Regulation. No 22 of 2008 regarding the Financial Arrangement of the Disaster Management on 28 February 2008 and Government Regulation No. 23 of 2008 regarding the Role and Function of International Organizations on Disaster Management on 28 February 2008.

${ }^{31}$ See The ASEAN charter, Art.1. 
tool for regional social engineering within Southeast Asian countries. At the end, integration marked by sharing common wisdoms will legitimize righteous and legal entitlement of the ASEAN human rights regime in Southeast Asian countries.

\section{CONCLUDING REMARKS}

This article has discussed the existence of the ASEAN human rights norms and mechanisms for effective and practical human rights advocacy and adjudication in order to reveal legal expectation for the Southeast Asian people. It may be recommended that better approach on thematic human rights issues should be highlighted in order to reveal the aforementioned expectation.

It reveals that there is tremendous influence for better human rights advocacy at strategic level within ASEAN cooperation. Unfortunately, it has less attention at the operational and tactical levels. At the same time, human rights adjudication has far beyond its reach due to its limited mandate and function. Remarkably, its institutionalization has led to public awareness and scrutiny for better improvement of its capacity in the future as requisite to establish a more powerful institution, that is the ASEAN Human Rights Court.

Wisdoms have been construed in legal manner creating distinct ASEAN human rights regime focussing on collective rights and thematic issues. Local wisdoms, especially, have been formalised in order to create distinct sub regional human rights norms and mechanisms contextualising way of life of the Southeast Asian peoples. One hand, it is true that there are still so many efficacies in terms of human rights enforcement mechanisms. On the other hand, it shows strong willingness to behave and to be bound by common legal wisdoms of legal rights of righteous and entitlement. 


\section{Bibliography}

\section{Books}

Beitz, Charles R. The Idea of Human Rights.London: Oxford University Press, 2009

Direktorat Jenderal Kerjasama ASEAN Deplu. ASEAN Selayang Pandang. 2007.

Holmes, JT. The Principle of Complementarity in Lee, R.S. (Ed). The International Criminal Court: The Making of the Rome Statute, Issues Negotiations Results. The Hague, Boston: Kluwer Law International, 1999

Holmes, JT. Complementarity: National Court vs. the ICC in Antonio Cassese et all. (eds). The Rome Statute of the International Criminal Court. London: Vol. I, Oxford University Press, 2002

Human Rights Resource Center, Rule of Law Untuk Hak Asasi Manusia di Kawasan ASEAN, Studi Data Awal, Jakarta: UI Press, 2001

Hunter, David, James Salzman, and Durwood Zaelke, International Environmental Law and Policy. New York: Foundation Press, 2002

Kjaerum, Mortem. National Human Rights Institution Implementing Human Rights. Leiden: Martinus Nijhoff Publisher, 2003

Katsumata, Hiro. ASEAN's Cooperative Security Enterprise, Norms and Interests in the ASEAN Regional Forum. Palgrave McMilan, 2009

Pacific Forum Secretariat. National Human Rights Institutions Pathways of the Pacific States. Pacific Islands Forum Secretariat, 2010

Rehman, J. International Human Rights Law, A Practical Approach. Longman: Pearson Education Limited, 2003

Stingen, Jo. The Relationship Between the International Criminal Court and National Jurisdictions, The Principle of Complementarity. Leiden: Martinus Nijhoff Publishers, 2008

Tood Landman. Studying Human Rights. New York: Routledge, 2006

Wahyuningrum, Yuyun. "Regional Limitation and Universality of Human Rights in ASEAN”. Paper Presentation at the Padjadjaran International Conference on International Law, Faculty of Law Padjajaran University - Bandung, 2013

Yigen, et all. National Human Rights Institutions: Articles and Working Papers. The Danish Center For Human Rights. Denmark: Wilden Plada, 2004 


\section{Journals}

Jaka Triyana, Heribertus. "Tinjauan Yuridis Tentang Badan HAM ASEAN Dalam Sistem Hukum Nasional Indonesia”. Mimbar Hukum 23, No. 3 (2011)

Jaka Triyana, Heribertus. "The Implementation of Natural Disaster Management Program in Indonesia Between 2007 and 2013", Mimbar Hukum 25, No. 1 (2011)

Luningning G, Camoying. "Establishing an ASEAN Human Rights Mechanism: Development and Prospects", Insights, Issue No. 1 (March 2005)

\section{Paper}

Jaka Triyana, Heribertus. "Politics and Law of Human Rights in Southeast Asia: A Critical Legal Analysis". Presented at the Short Course on Human Rights and Democracy in Southeast Asia for the ASEAN Diplomats, 24-25 August 2009. Pusat Studi Sosial Asia Tenggara (PSSAT UGM)-Deplu RI, Yogyakarta, 2009

\section{Legal Documents}

ASEAN Masterplan 2020

ASEAN Human Rights Declaration

Charter of the Southeast Asian Nations

Government Regulation No. 22 of 2008 regarding the Financial Arrangement of the Disaster Management

Government Regulation No. 23 of 2008 regarding the Role and Function of International Organizations on Disaster Management

Human Rights Committee, General Comment 3, Article 2, para 1, Implementation at the national level (Thirteenth session, 1981), Compilation of General Comments and General Recommendations Adopted by Human Rights Treaty Bodies, UN Doc. HR1/GEN/1/Rev.1 at 4 (1994)

Law of the Republic of Indonesia No. 39 of 1999 concerning Human Rights

Law of the Republic of Indonesia No. 24 of 2007 concerning Natural Disaster Management Process

Phnom Penh Statement on the Adoption of the ASEAN Human Rights Declaration (AHRD). 18 November 2012 
Terms of References ASEAN Intergovernmental Commission on Human Rights

\section{Internet}

Asian Disaster Preparedness Center, Critical Guidelines Community-Based Disaster Risk Management (Bangkok, 2006), 28-45.http://www.preventionweb. net/files/9440_ADPCCriticalGuidelines.pdf

United Nations High Commissioner for Human Rights. Frequently Asked Questions on A Human Rights Based Approach to Development Cooperation. New York: UN Publisher, 2006.http://www.ohchr.org/Documents/Publications / FAQen.pdf ident-obama-kenyan-people 